\title{
Paleomagnetism of latest Anisian (Middle Triassic) sections of the Prezzo Limestone and the Buchenstein Formation, Southern Alps, Italy
}

\author{
G. Muttoni ${ }^{a}$, D.V. Kent ${ }^{b}$ \\ a Dipartimento di Scienze della Terra, Universita' degli Studi di Milano, via Mangiagalli 34, 20133 Milan, Italy \\ ${ }^{b}$ Lamont-Doherty Earth Observatory, Columbia University, Palisades, NY 10964, USA
}

(Received September 13, 1993; revision accepted January 24, 1994)

\begin{abstract}
A paleomagnetic study was carried out at six stratigraphic sections (309 specimens) in the latest Anisian (Middle Triassic) Prezzo Limestone and the overlying Buchenstein Formation. These units outcrop over a wide area in the western Southern Alps, although most of the sampled sections are in the vicinity of the Late Eocene-Early Oligocene Adamello batholith. Three sites suffered a complete remagnetization induced by the Adamello, whereas a characteristic component with a positive fold test has been isolated at the three other sites. The mean pole of the characteristic component (Lat. $63.2^{\circ} \mathrm{N}$, Long. $229.3^{\circ} \mathrm{E}, N=3, A_{95}=8^{\circ}, k=236$ ) is in agreement with the Triassic portion of the West Gondwana apparent polar wander path (APWP), supporting the use of paleopoles from well-dated rocks in the Southern Alps as useful proxies for the African APWP. The characteristic component, where isolated in the sampled sections, is of normal polarity only, corresponding to the latest Anisian on the basis of well-defined ammonoid and conodont biostratigraphy, but the present results suggest that there are good opportunities for extending Middle Triassic magnetostratigraphy in these Southern Alps rock units. The mean pole of the Adamello-induced component (Lat. $74.5^{\circ} \mathrm{N}$, Long. $172.1^{\circ} \mathrm{E}, N=4, A_{95}=7.6^{\circ}, K=145$ ) lies close to the Early Tertiary portion of the APWP for stable Europe. The post-folding, Adamello-induced directions confirm that the 30-42 Ma Adamello batholith intruded after Alpine deformation and that no further deformation apparently occurred in post-emplacement times.
\end{abstract}

\section{Introduction}

The Southern Alps have been the object of over three decades of paleomagnetic research on Late Paleozoic-Tertiary rocks [1]. The Southern Alps are thought to be autochthonous. The Paleozoic and Mesozoic paleomagnetic directions

$\overline{\mathrm{RvdV}]}$ generally appear consistent and have an African affinity [2].

The paleomagnetic research carried out here is focused mainly on the latest Anisian (Middle Triassic) Prezzo Limestone and the overlying Buchenstein Formation. These units outcrop over a wide area in the western Southern Alps and have a well-defined ammonoid and conodont zonation, which is essential for the ongoing definition of the Anisian/Ladinian boundary $[3,4]$. 
The six stratigraphic sections sampled are classic fossiliferous localities of the Middle Triassic of the Southern Alps (Figs. 1 and 2), but most of them outcrop in the vicinity of the Late EoceneEarly Oligocene (42-30 Ma) [5] Adamello batholith. This has to be taken into account when defining the characteristic magnetization of the limestones because remagnetization of the intruded country rock is to be expected [6]. Because Triassic limestones in the Southern Alps have barely been the object of paleomagnetic analyses, the data presented here in the context of a regional fold test should be of general interest for establishing the suitability of these rocks as reliable paleomagnetic recorders of magnetostratigraphy and for tectonic inter

\section{Geological setting}

The sections studied are located in the western Southern Alps (Fig. 1) and belong to the Lombardian Basin, which is characterized by a thick Mesozoic sedimentary sequence. The sections occur in the upper part of the Prezzo Limestone and in the lower part of the Buchenstein Formation (Fig. 2).

The Prezzo Lst. consists of up to $90 \mathrm{~m}$ of $20-25 \mathrm{~cm}$ thick beds of grey to black limestones alternating with black marls, whereas the Buchenstein Fm. is made up of $40-70 \mathrm{~m}$ of cherty limestones, locally with tuffite levels.

The stratigraphic sections are as follows (Fig. a) Cits 1 is the Stabol Fresco composite section

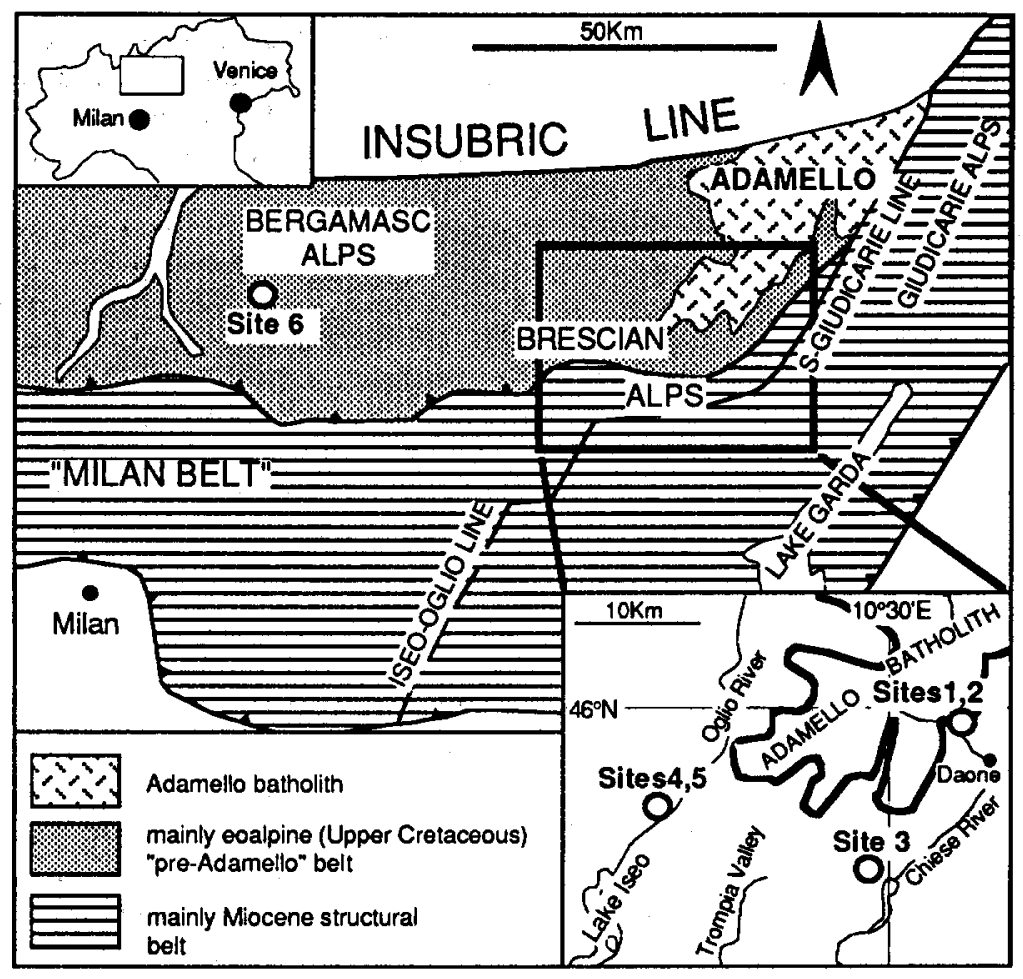

Fig. 1. Simplified tectonic map of the western Southern Alps (slightly modified from [11]) showing the location of the sampling sites. Sites 1 and 2 =upper Daone valley (Giudicarie Alps); site $3=$ Romanterra (Caffaro valley); site $4=$ Contrada Gobbia (Camonica valley); site $5=\mathrm{La}$ Baita (Camonica valley); site $6=$ Lenna (Brembana valley). 
of Kovàcs et al. [7], which includes a total of 24.5 $\mathrm{m}$ of Prezzo Lst. and $10 \mathrm{~m}$ of Buchenstein Fm. at three subsections (I, II and III), together with the Adana section (11 m of Prezzo Lst.); a $0.5 \mathrm{~m}$ thick Adamello discordant dyke is present at Stabol Fresco II. Site 2 is the Avalina short section, located about $1 \mathrm{~km}$ south of the Stabol Fresco in a few metres of Prezzo Lst. Site 3 includes $12 \mathrm{~m}$ of Buchenstein Fm., in the basal part of Brack and Rieber's Romanterra section [8]. Site 4 is the
Contrada Gobbia section of Kovàcs et al. [7] with $7.8 \mathrm{~m}$ of Prezzo Lst. and characterized by four Adamello discordant dykes in its upper part. Site 5 is the La Baita section of Kovàcs et al. [7] (4.55 $\mathrm{m}$ of Prezzo Lst.). Finally, site 6 is the Lenna section, the westernmost and most distant from Adamello, comprising the uppermost $20 \mathrm{~m}$ of the Prezzo Lst.

The sections are provided with ammonoid zonation. Three sequential latest Anisian zones

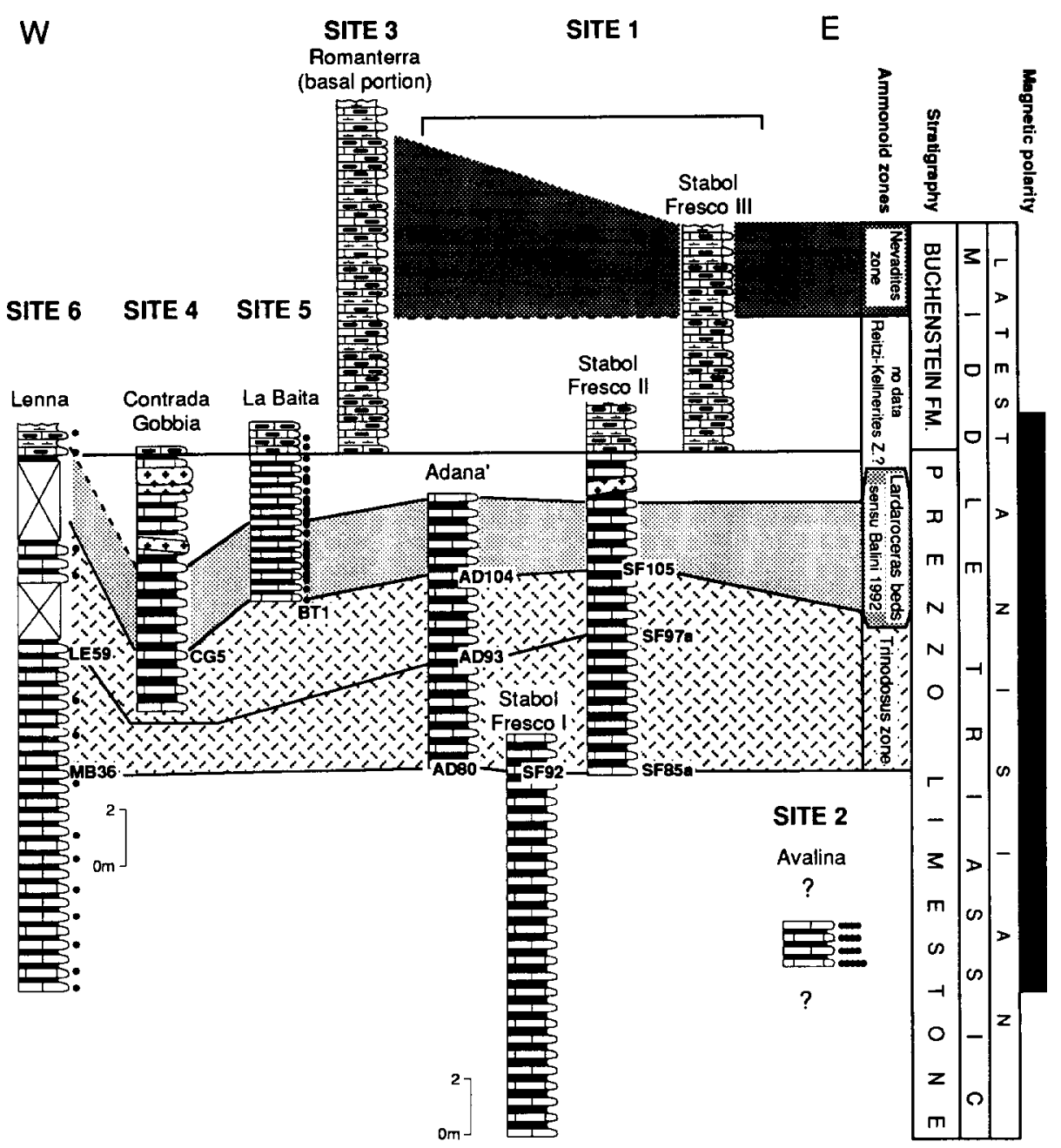

Fig. 2. Gross lithology, biostratigraphy and magnetic polarity interpretation of the sampled sections. Three ammonoid zones have been recognized: Trinodosus zone, Lardaroceras beds sensu Balini [9], and Nevadites zone. The sections are latest Anisian (Middle Triassic) in age. At sites 2, 5 and 6, the dots represent the position of sample levels where the pre-folding characteristic remanence, only of normal polarity, has been resolved. 
have been recognized [3], the Trinodosus zone, Lardaroceras beds sensu Balini [9], and the Nevadites zone.
The time interval covered by these sections is a matter of debate. According to Haq et al. [10], the duration of the entire Anisian is 4 m.y. If

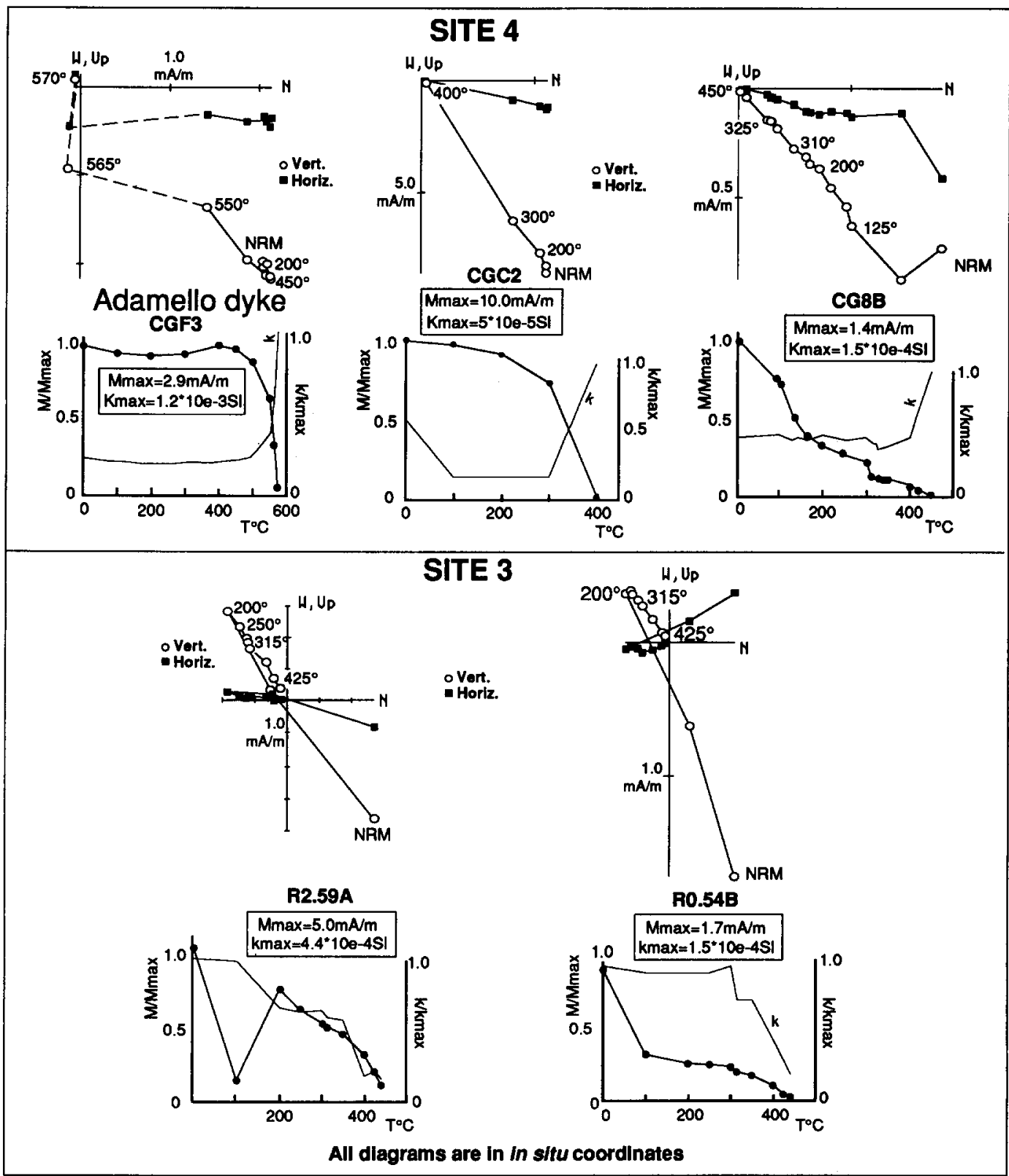

Fig. 3. Vector end point thermal demagnetization diagrams (geographic coordinates) and decay curves of the NRM of representative samples from sites 3 and 4 which are dominated by Adamello-induced components. $O=$ projections on the vertical plane; $\square=$ projections on the horizontal plane. 
there are seven ammonoid zones for the Anisian of the western Tethys, the mean duration of each ammonoid zone would be about 570 k.y. Because there are at least three zones present in the studied sections (Fig. 2), the duration of the Prezzo Lst. and the Buchenstein Fm. is $>1.7$ m.y.
Structurally, the sampling localities belong to the pre-Adamello Orobic, Grigna and Presolana areas [11], the most internal part of the western Southern Alps striking westward from the Giudicarie lineament to the Ivrea-Verbano zone (Fig. 1). A main geological feature of this area is the Late Eocene-Early Oligocene Adamello batho-
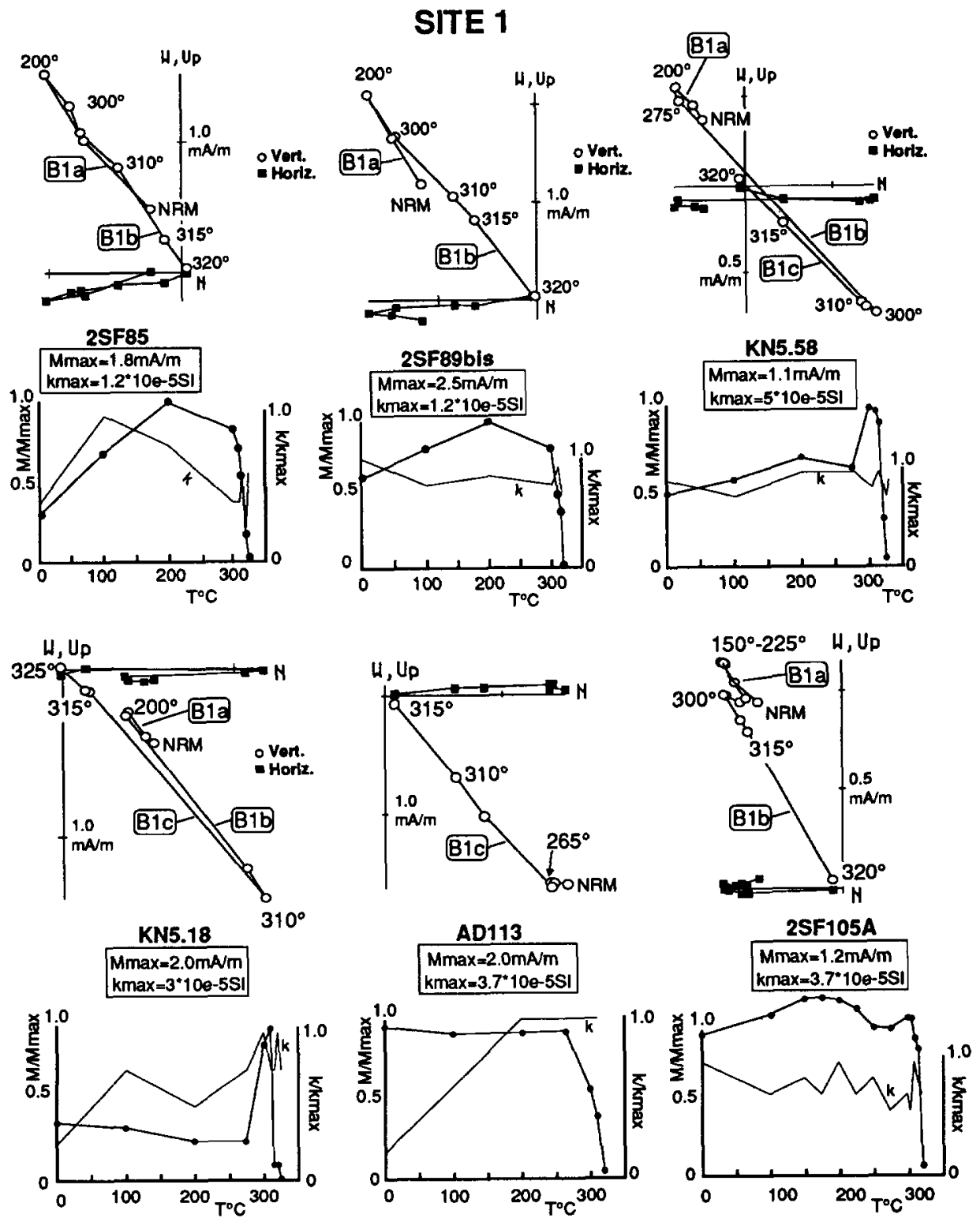

All dlagrams are in In situ coordinates

Fig. 4. Vector end point thermal demagnetization diagrams (geographic coordinates) and decay curves of the NRM of representative samples from site 1 (Adamello-induced components). For symbols, see Fig. 3. 
lith, a typical composite batholith with ages that decrease regularly from 42 to $30 \mathrm{Ma}$ from southwest to northeast, representing successive intrusions of fast-cooling bodies [5]. Field observations clearly demonstrate that the Adamello cut across pre-existing large-scale Alpine folds in the Triassic sedimentary cover and is, at least with regard to these folding events, post-tectonic [5,12]. From this and other evidence, the severe deformation and shortening which affected the pre-Adamello Orobic, Grigna and Presolana areas has been attributed essentially to the Late CretaceousPaleogene 'eoalpine crisis' [11]. Recently, Neogene (i.e., post-Adamello) deformations in the pre-Adamello chain have also been inferred [13]. Some authors believe that these Neogene deformations played only a marginal role in the tectonic development of the area because there is hardly any deformation of the Adamello batholith and related dykes [11].

Five (sites 1 to 5) of the six sampling sites are located around the southern and oldest (40-42 Ma) part of the Adamello intrusion (Fig. 1) and two of them (sites 1 and 4) bear Adamello-related dykes. The paleomagnetic overprints associated with the Adamello intrusion, however, provide useful information for testing the geometric relationships between the Adamello emplacement and the folded country rock for evidence for any syn- or post-intrusion deformation in the studied area.

\section{Sampling and laboratory techniques}

The samples were taken with a portable water-cooled petrol-powered drill and oriented by means of a magnetic compass. Almost every calcareous bed was sampled in each section, resulting in an average spacing of about $30-40 \mathrm{~cm}$ between sampling levels. From each $2.5 \mathrm{~cm}$ diameter core sample one or, more rarely, two standard $11 \mathrm{~cm}^{3}$ specimens were cut, yielding a total of 309 specimens for analysis. The specimens were subjected to complete stepwise thermal demagnetization. Remanence measurements were performed on a $2 \mathrm{G}$ three-axis cryogenic magnetometer in a magnetically shielded room. Magneto- chemical alteration was monitored after each heating step by measurements of low field magnetic susceptibility with a Bartington MS2 meter.

Principal component analysis [14] was used to determine the component directions chosen by inspection of vector end point demagnetograms. Mean directions were calculated by standard Fisherian statistics. For rock magnetic characterization, isothermal remanent magnetization (IRM) was imparted to selected fresh samples and thermally demagnetized using the method of Lowrie [15].

\section{Paleomagnetic directions}

\subsection{Adamello-induced components (sites 1, 3 and 4)}

Sites 1,3 and 4 provided demagnetization trajectories with in-situ steep north-and-down (or south-and-up) directions that are believed to be entirely Adamello-induced.

At site 4 vector end point demagnetograms show only $\mathrm{N}$-and-down directions isolated between 100 and $450^{\circ} \mathrm{C}$, whereas at site 3 only S-and-up directions, isolated from 200 to $425^{\circ} \mathrm{C}$, are revealed following the removal of a soft component carrying the present-day field (Fig. 3). The thermal decay of the NRM, with intensities ranging from about 1 to $5 \mathrm{~mA} / \mathrm{m}$, indicates the presence of a magnetic phase with a maximum unblocking temperature of about $450^{\circ} \mathrm{C}$, although a decrease in the thermal decay curve around $300^{\circ} \mathrm{C}$ is also observed at site 4 . Magnetic susceptibility is generally low $\left(\sim 10^{-4} \mathrm{SI}\right)$.

At site 4, an Adamello dyke and its baked contact have also been sampled. The directions of the Adamello dyke (Fig. 3, sample CGF3) and of the baked limestone (sample CGC2) are all very similar to the unbaked limestone (sample CG8B) at the site. The Adamello dyke bears a maximum unblocking temperature narrowly distributed between 550 and $570^{\circ} \mathrm{C}$, pointing to the presence of magnetite. The strong increase in susceptibility observed above $500-550^{\circ} \mathrm{C}$ is probably due to the formation of an alteration phase (more mag- 


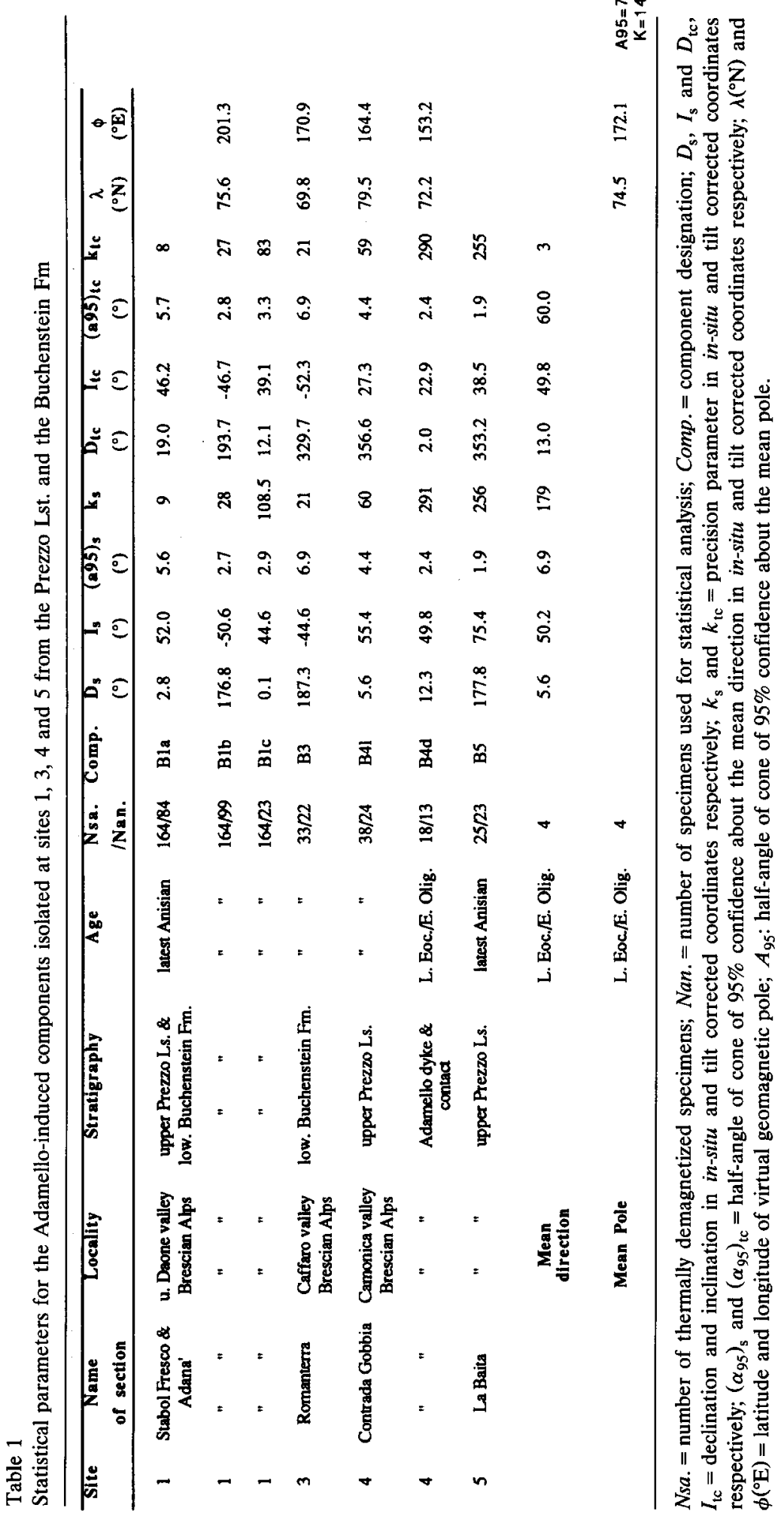




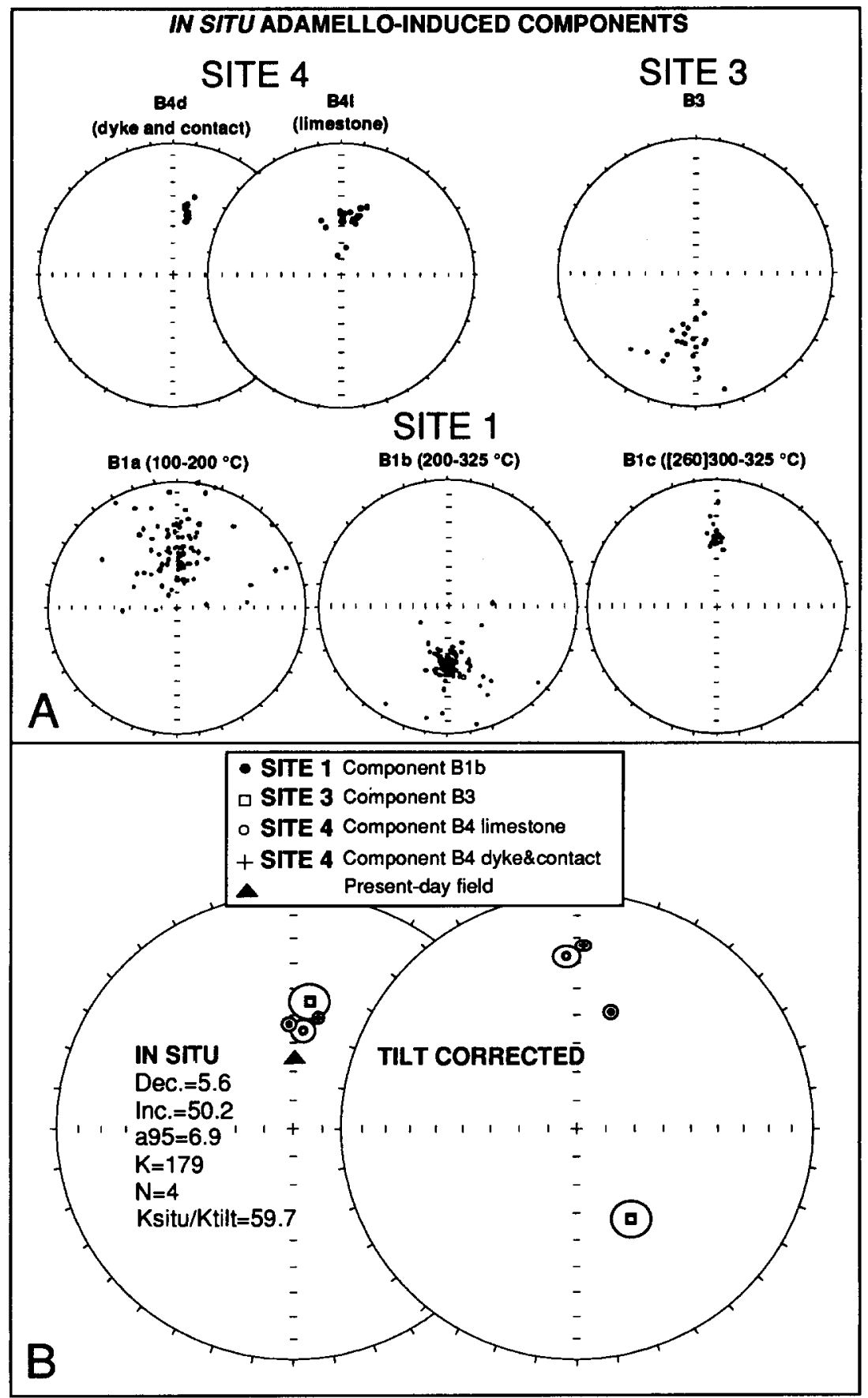

Fig. 5. (A) Stereographic projections of sample magnetization directions isolated from sites 1,3 and 4 (Adamello-induced components, Table 1). (B) Site-mean Adamello-induced component directions from sites 1, 3 and 4 before (in situ) and after bedding tilt correction. 


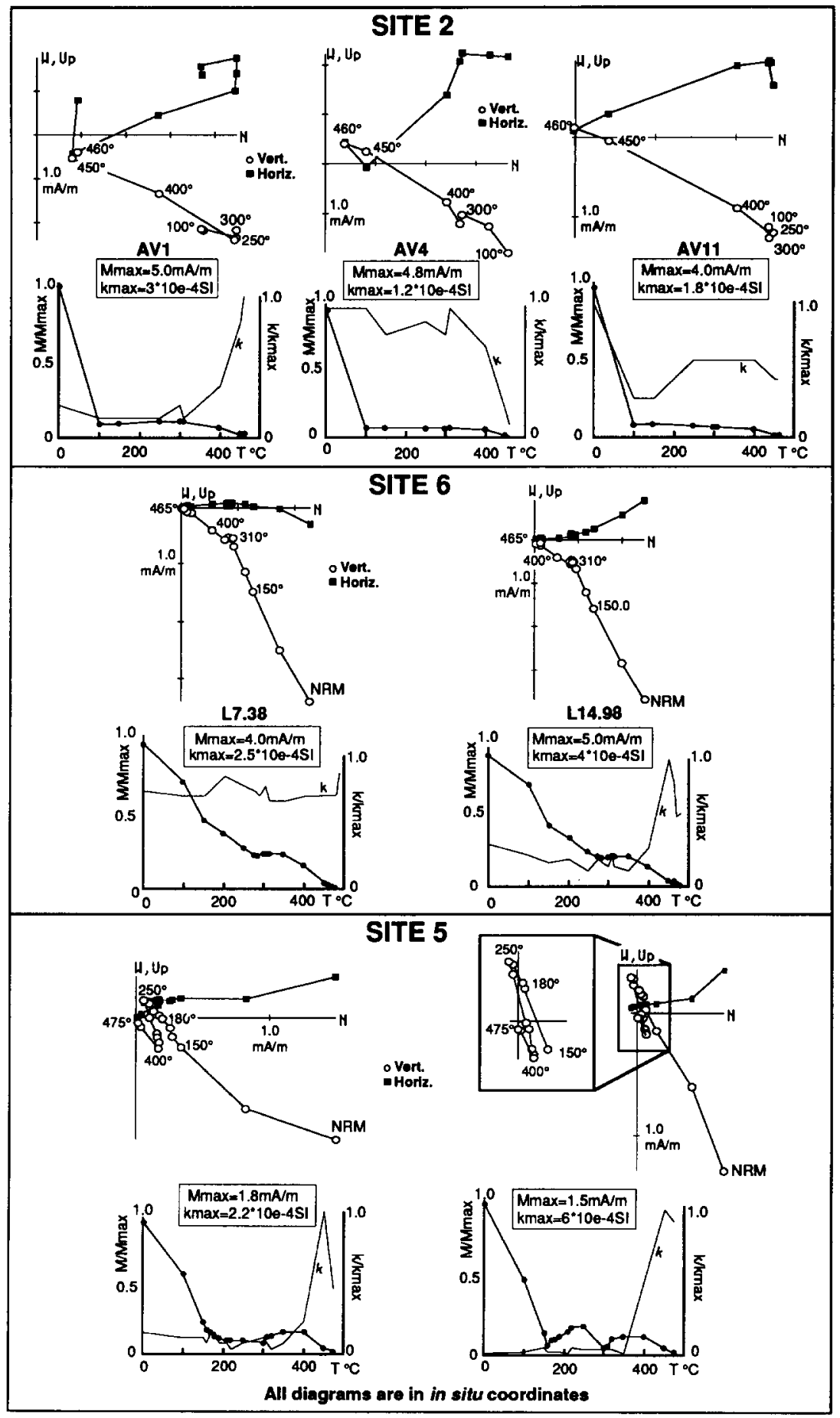

Fig. 6. Vector end point thermal demagnetization diagrams (geographic coordinates) and decay curves of the NRM of representative samples from sites 2,5 and 6 (pre-folding characteristic components). For symbols, see Fig. 3. 
netite?), which causes instability in the direction of the remanence at the final steps.

Site 1 shows more complicated behaviour (Fig. 4). Vector end point demagnetograms illustrate the presence of at least three antiparallel demagnetization trajectories, labelled $\mathrm{B} 1 \mathrm{a}$ ( $\mathrm{N}$-anddown), B1b (S-and-up) and B1c (N-and-down), that can coexist in a single specimen. Usually a positive direction (B1a) is first unblocked from NRM to $200^{\circ} \mathrm{C}$ and subsequently an antiparallel negative direction (B1b) is isolated up to $320^{\circ} \mathrm{C}$ (samples 2SF85 and 2SF89bis). Sometimes, the $\mathrm{B} 1 \mathrm{a}$ and B1b directions are followed by a third positive direction (B1c) that is unblocked in the very last steps from $310^{\circ}$ to $320^{\circ}$ or $325^{\circ} \mathrm{C}$ (samples KN5.58 and KN5.18). This general picture can be even more complex, with zig-zag demagnetization trajectories between $\mathrm{NRM}$ and $300^{\circ} \mathrm{C}$, i.e. between B1a and B1b (sample 2SF105A). Whatever the exact case, the thermal decay of NRM suggests the presence of a phase with a maximum unblocking temperature of $320^{\circ} \mathrm{C}$ (Fig. 4). Magnetic susceptibility is low $\left(<10^{-4} \mathrm{SI}\right)$ and shows no appreciable variation over the unblocking spectrum of the stable remanence.

To summarize (Table 1 and Fig. 5A), N-anddown directions were obtained from the Prezzo Lst. as well as from an Adamello dyke and baked limestone at site 4 , whereas essentially antiparallel S-and-up directions were obtained from the Buchenstein Fm. at site 3. Site 1 in the Prezzo Lst. and Buchenstein Fm. gave three coexisting trajectories, oriented $\mathrm{N}$-and-down and S-and-up; the antiparallelism of these trajectories is confirmed by the relatively small departures from colinearity between $\mathrm{B} 1 \mathrm{a}$ and $\mathrm{B} 1 \mathrm{~b}\left(4.0^{\circ}\right)$ and between $\mathrm{B} 1 \mathrm{~b}$ and $\mathrm{B} 1 \mathrm{c}\left(6.4^{\circ}\right)$. Each of these magnetizations is significantly different from the presentday dipole field ( $\operatorname{Inc}=64^{\circ}$ ) direction for the sampling area.

The fact that the Adamello dyke and the Prezzo Lst. at site 4 share similar directions leads to the conclusion that the $\mathrm{N}$-and-down and antiparallel S-and-up components isolated at sites 1 , 3 and 4 are genetically related to the Adamello batholith. This is confirmed by the geographical proximity of these localities to the intrusion and, more substantially, by the fact that similar direc- tions have been observed by Kipfler and Heller [6] in Upper Permian redbeds ( $D e c=11.4^{\circ}$, Inc $=61.0^{\circ}, N_{\text {samples }}=48, \alpha_{95}=4.0^{\circ}$ ) and metasandstones $\left(\operatorname{Dec}=8.1^{\circ}, \operatorname{Inc}=54.2^{\circ}, N_{\text {samples }}=15, \alpha_{95}\right.$ $=6.6^{\circ}$ ) in the contact aureole, a few kilometres southwest of site 1 . Finally, the directions detected at sites 1,3 and 4 are well grouped in in-situ coordinates $(k=179)$ and become significantly more scattered after correction for bedding tilt $(k=3)$, suggesting that they have been acquired after deformation (Fig. 5B).

\subsection{Characteristic components (sites 2, 5 and 6)}

Demagnetization trajectories with $\mathrm{N}$ - to NWand-down directions have been isolated at sites 2 , 5 and 6 and may represent a record of the Triassic paleomagnetic field.

Samples from sites 2 and 6, after removal of a present-day field component, bear a NW-anddown characteristic component with a direction that is distinctively gentler than the Adamello-induced (and present-day field) directions.

Site 5 is more complex. Vector end point demagnetograms reveal three progressively isolated components (Fig. 6): a present-day field component is removed first as for sites 2 and 6 , then a component with southerly declinations and distinctively steep negative inclinations is resolved between about 250 and $400^{\circ} \mathrm{C}$, and finally a NWand-down characteristic component is revealed between 400 and $475^{\circ} \mathrm{C}$. The S-and-up component is similar to the Adamello-induced directions; its anomalously high inclination is attributed to partial overlap with the present-day and characteristic components.

At sites 2, 5 and 6 the intensity of NRM generally ranges from 1 to $5 \mathrm{~mA} / \mathrm{m}$. Thermal decay of NRM shows the presence of a magnetic phase with a maximum unblocking temperature of $450-480^{\circ} \mathrm{C}$ (Fig. 6). Magnetic susceptibility sometimes shows a rapid increase above 350$400^{\circ} \mathrm{C}$ due to the formation of a secondary high susceptibility phase but does not seem to affect the recovery of the characteristic remanence.

The characteristic directions in in-situ coordinates are distributed in distinct groups by site, each different from the Adamello-induced direc- 


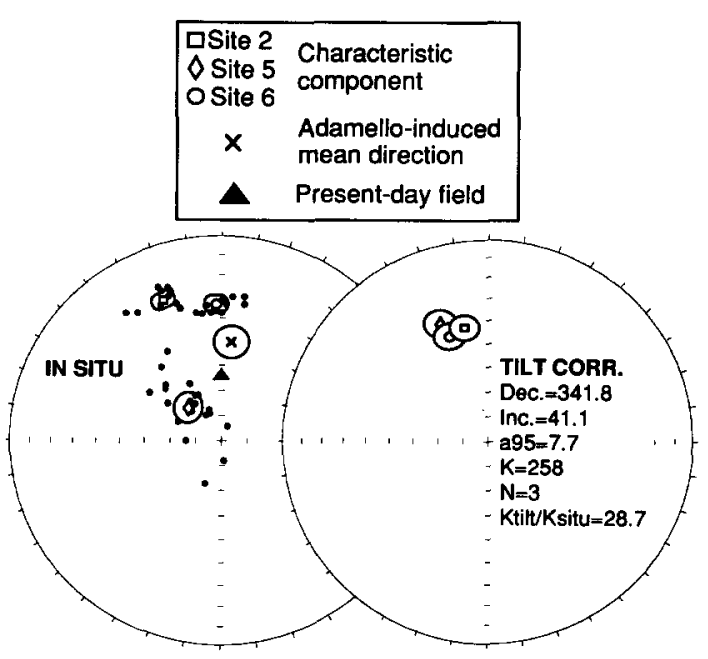

Fig. 7. Site-mean characteristic directions from sites 2,5 and 6 before (in situ) and after bedding tilt correction. tions and from the present-day field (Fig. 7 and Table 2). After corrections for tilting, the sitemean directions converge. The precision parameter of the three site-mean directions increases by a factor of 28.7 with full $(100 \%)$ correction for bedding tilt, providing a positive fold test significant at the $99 \%$ level of confidence according to the criteria of both McElhinny [16] and McFadden and Jones [17]. Although the best grouping occurs at somewhat less than full tilt correction, the possibility of a syn-folding remagnetization is not well supported because the increase by a factor of only 1.9 in the precision parameter at this intermediate $(88 \%)$ step of tilt correction compared to that at full (100\%) tilt correction is not statistically significant. Accordingly, the characteristic magnetization $\left(\mathrm{Dec}=341.8^{\circ}, \quad\right.$ Inc $=$ $41.1^{\circ}, N_{\text {sites } / \text { samples }}=3 / 43$ ) is a good candidate for

Adamello-induced remanence
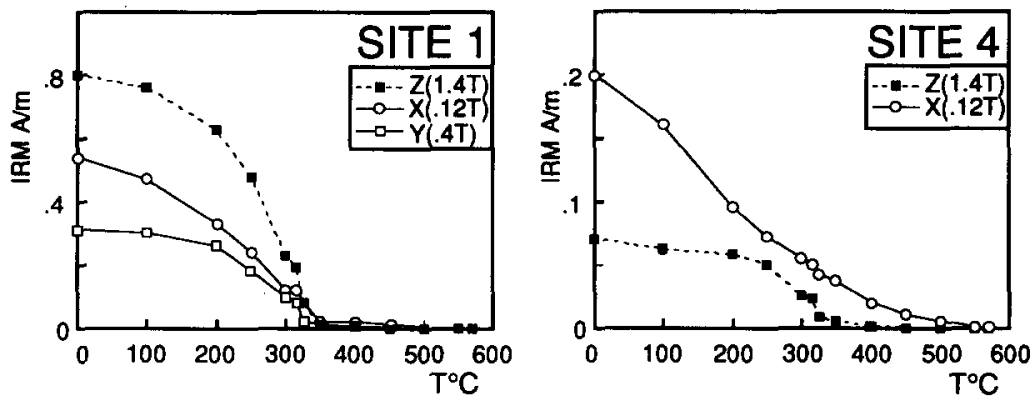

Characteristic remanence
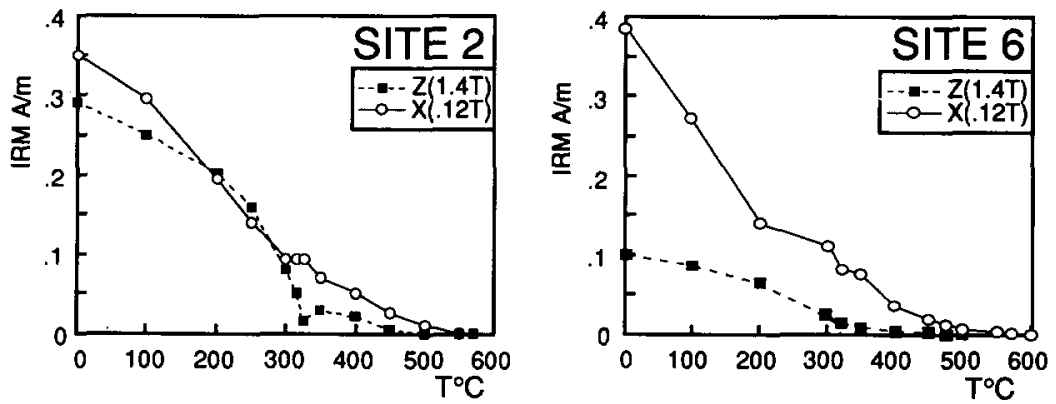

Fig. 8. Representative thermal decay of three-axis IRM for samples from sites 1 and 4 (with Adamello-induced components) and sites 2 and 6 (with the pre-folding characteristic components), obtained inducing $1.4 \mathrm{~T}$ along the $z$-axis, $0.4 \mathrm{~T}$ along the $y$-axis and $0.12 \mathrm{~T}$ along the $x$-axis. The $y$-axis IRM $(0.4 \mathrm{~T})$ generally showed unblocking spectra similar to the $z$-axis IRM (1.4 T) and these were therefore combined to represent the hard coercivity fraction $(>0.12 \mathrm{~T})$ for comparison to the softer coercivity fraction $(<0.12 \mathrm{~T})$ of IRM for display purposes for sites 2,4 and 6 . 


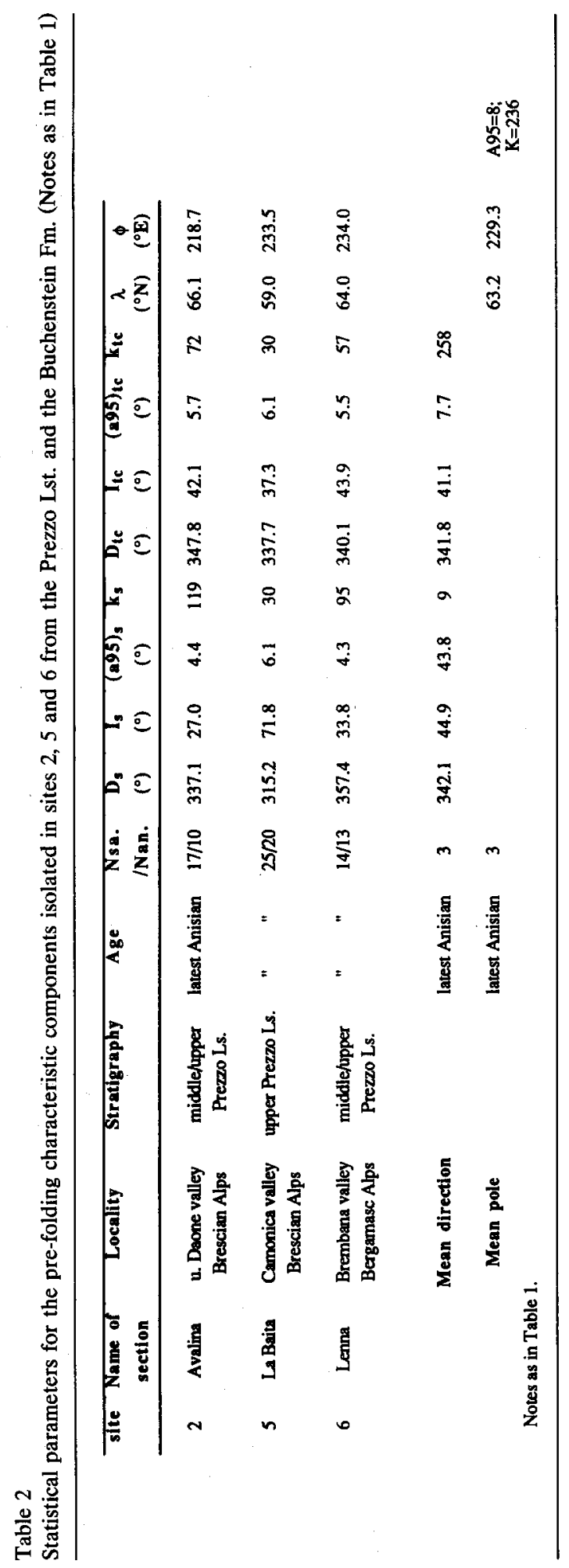


representing the Middle Triassic paleomagnetic field.

\section{Rock magnetic properties}

The ferromagnetic phases and their magnetic properties have been defined mainly with the aid of thermal unblocking characteristics of isothermal remanent magnetization (IRM) by the method of Lowrie [15]. Selected fresh specimens from each of the sampling sites (except site 3, where all specimens had already been thermally demagnetized) were given an IRM first along the $z$-axis in a direct field of $1.4 \mathrm{~T}$, then along the $y$-axis in $0.4 \mathrm{~T}$, and finally along the $x$-axis in a field of $0.12 \mathrm{~T}$. The composite IRM was subjected to progressive thermal demagnetization to determine the unblocking temperature spectra of the different coercivity fractions of IRM. The $y$-axis IRM $(0.4 \mathrm{~T})$ generally showed unblocking spectra similar to the $z$-axis IRM (1.4 T) and these were therefore usually combined to represent the hard coercivity fraction $(>0.12 \mathrm{~T}$ ) for comparison to the softer coercivity fraction $(<0.12 \mathrm{~T})$ of IRM for display purposes (Fig. 8).

\subsection{Sites 1,3 and 4}

Considering first the three sites dominated by Adamello-induced magnetizations, recall that site 1 is located less than $2 \mathrm{~km}$ from the nearest outcrop of the Adamello batholith, while sites 3 and 4 are slightly more distant. At site 1 thermal decay of IRM shows narrowly distributed unblocking temperatures between 300 and $320^{\circ} \mathrm{C}$ (Fig. 8). The shape of the thermal decay curves of the hard and softer coercivity fractions are similar, with the hard coercivity fraction dominating in some specimens (see Fig. 8) but being subordinate to the softer coercivity fraction in others. These properties are consistent with a magnetic mineralogy consisting mainly of pyrrhotite with a broad range of coercivities probably related to different grain sizes.

At site 4 the curve for the hard coercivity component shows a concentration of unblocking temperatures around $300-320^{\circ} \mathrm{C}$ (Fig. 8), proper- ties again compatible with pyrrhotite. However, an appreciable amount of magnetic mineral with a maximum unblocking temperature of $570^{\circ} \mathrm{C}$ is revealed by the unblocking temperature spectrum of the softer IRM component and these properties suggest that magnetite is also present in these specimens. Although thermal demagnetization of IRM has not been performed on specimens from site 3 , the presence of at least magnetite is suggested by the thermal decay of NRM which shows unblocking temperatures extending to $425^{\circ} \mathrm{C}$ or more.

\subsection{Sites 2, 5 and 6}

The magnetic mineralogy encountered in the three sites which carry a pre-folding characteristic magnetization (sites 2, 5 and 6) is surprisingly very similar to that described for site 4 . Thermal demagnetization of IRM typically reveals an appreciable softer component with a maximum unblocking temperature of about $570^{\circ} \mathrm{C}$ as well as a harder component with unblocking temperatures concentrated around $320^{\circ} \mathrm{C}$ (Fig. 8). Thus, the pyrrhotite-magnetite assemblage is found to be associated with not only specimens dominated by an Adamello-related remagnetization (site 4), but with those that carry a characteristic remanence as well (sites 2, 5 and 6).

These observations lead to the conclusion that the Adamello overprint can be carried by pyrrhotite as well as by magnetite, whereas the characteristic magnetization is carried only by magnetite. The formation of pyrrhotite may be related to metamorphic processes caused by the emplacement of the Adamello batholith. Rock magnetic evidence for pyrrhotite is found at most of the sampling sites, including site 1 , the closest to the Adamello intrusion and where it is the predominant magnetic carrier, at site 4 , which contains Adamello dykes, and even at site 6, located $50 \mathrm{~km}$ west of the main Adamello exposure. Magnetite is presumed to be of primary or early diagenetic origin and carries the characteristic magnetization at sites 2,5 and 6 . However, magnetite is also present at sites 3 and 4 where it has evidently been completely reset into Adamello directions. 
Partial (site 5) to complete (sites 1, 3 and 4) remagnetization was most likely due to thermochemical effects associated with the Adamello intrusion. Significant regional heating to more than $300^{\circ} \mathrm{C}$, as suggested by conodont alteration [A. Nicora, pers. comm., 1992], may also have been caused by other source mechanisms, such as tectonic loading due to nappe emplacement during the Alpine orogeny [18]. The existence of antiparallel demagnetization trajectories within individual specimens at site 1 may be related to the cooling history. Rochette et al. [19] have reported that single samples of pyrrhotite-bearing metamorphic calcschists from the Dauphinois (Western Alps) recorded up to seven successive polarity intervals during slow cooling of the region in the Late Tertiary. If thermoremanence was also the mechanism of remanence acquisition in the site 1 rocks studied here, the $B 1 a, B 1 b$ and B1c components of magnetization could be inter- preted in a similar way, as representing at least two successive polarity inversions captured within individual specimens. Unfortunately, there are too few reversals to apply Rochette et als.' method to calculate a cooling model for the region.

\section{Discussion}

The limestones of the Prezzo Lst. and Buchenstein $\mathrm{Fm}$. were able to preserve a record of ancient magnetic fields even though the magnetizations were rather complex: three sites suffered a complete remagnetization most likely caused by the Adamello intrusion, whereas three other sites provided a pre-folding characteristic component. Paleopoles for the pre-folding characteristic component $\left(\mathrm{PR}_{1}\right)$ and for the post-folding Adamelloinduced component $\left(\mathrm{PR}_{2}\right)$ have been calculated from the site-mean pole positions. These pale-

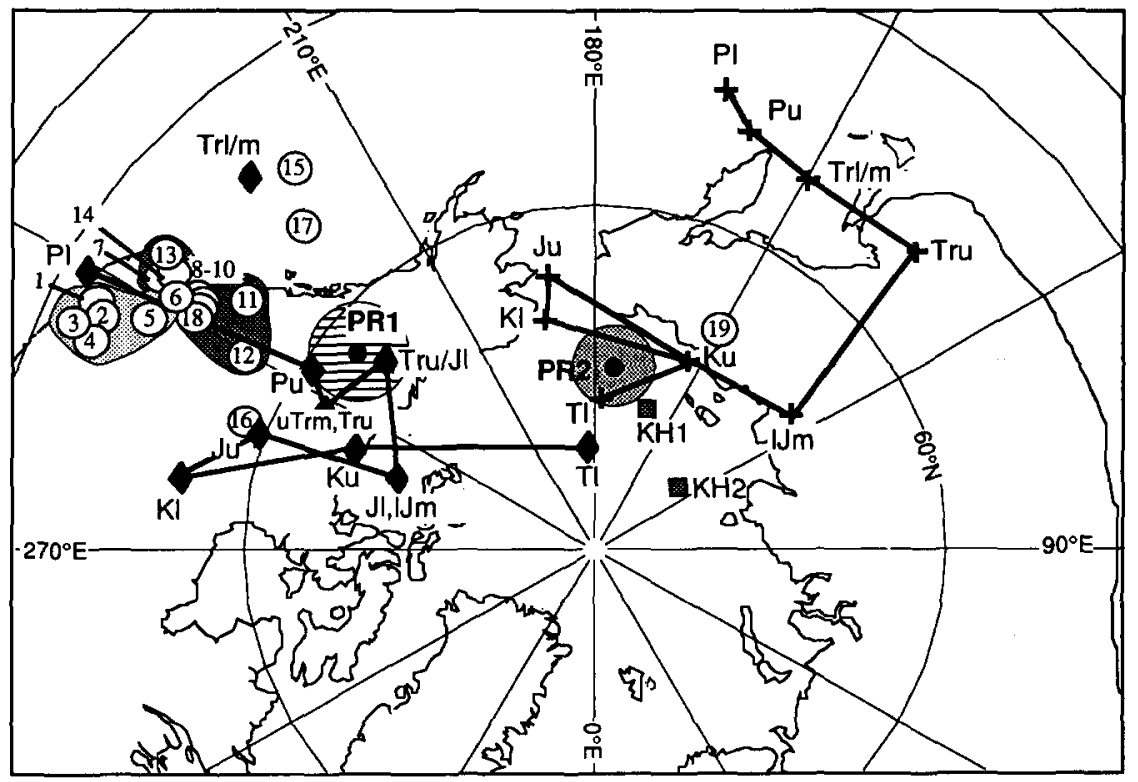

Fig. 9. The apparent polar wander paths (APWP) (mean poles from [1]) for stable Europe (heavy line with crosses) and for West Gondwana in northwest African coordinates (heavy line with diamonds), compared to the $\mathrm{PR}_{2}$ pole from the Adamello-induced overprint and the $\mathrm{PR}_{1}$ pole from the pre-folding characteristic components (with an $\alpha_{63}$ error circle) from this study of latest Anisian Prezzo Lst. and Buchenstein Fm. of the Southern Alps, $\mathrm{KH}_{1}$ and $\mathrm{KH}_{2}$ poles of Kipfler and Heller [6] from remagnetized Upper Permian metasandstones and redbeds, respectively, from the Adamello contact aureole, and Permian-Triassic poles from the Southern Alps (encircled numbers keyed to Table 3). Age symbols: $P l=$ Lower Permian; $P u=U p p e r$ Permian; $T r l / m=$ Lower/Middle Triassic; $u$ Trm $=$ upper Middle Triassic; $T r u=$ Upper Triassic; Tru $/ J=$ Upper Triassic $/$ Lower Jurassic; $l l=$ Lower Jurassic; $J m=$ lower Middle Jurassic; $J u=$ Upper Jurassic; $K l=$ Lower Cretaceous; $K u=$ Upper Cretaceous; $T l=$ Lower Tertiary. 
opoles have been compared with the apparent polar wander path (APWP) of stable Europe and of West Gondwana (Africa and South America, in northwest African coordinates), following the recent review of Van der Voo [1] (Fig. 9).

The $\mathrm{PR}_{1}$ mean pole (Lat. $63.2^{\circ} \mathrm{N}$, Long.

Table 3

Permian and Triassic pole positions from the Southern Alps with quality index $Q \geqslant 3$ (except pole 19, where $Q=2$ ) compiled from Van der Voo [1]

\begin{tabular}{|c|c|c|c|c|c|c|c|c|c|}
\hline & $\mathbf{n}$ & Rock Unit & Locality & Age & $\begin{array}{c}\lambda \\
(\mathbf{N})\end{array}$ & $\begin{array}{c}\phi \\
\left({ }^{\circ} \mathbf{E}\right)\end{array}$ & $\mathbf{k}$ & 295 & Reference \\
\hline $\begin{array}{l}\cdot 0 \\
0 \\
0 \\
\infty \\
\frac{1}{2} \\
1\end{array}$ & $\begin{array}{c}19 \\
18 \\
\text { PR1 } \\
17 \\
16\end{array}$ & $\begin{array}{c}\text { Norian dolostones } \\
\text { Ladinian-Camian } \\
\text { volcanics } \\
\text { Prezzo Limestone } \\
\text { Valle di Scalve } \\
\text { porphyries } \\
\text { Trl/m Vicentinian } \\
\text { Alps combined }\end{array}$ & $\begin{array}{c}\text { Dolomites } \\
\text { W Southern } \\
\text { Alps } \\
\text { Lombardy } \\
\text { Vicentinian Alps }\end{array}$ & $\begin{array}{c}227-233 \\
\text { latest Anisian } \\
\quad \approx 235 \\
232-238\end{array}$ & $\begin{array}{l}48 \\
63\end{array}$ & $\begin{array}{l}240 \\
229\end{array}$ & $\begin{array}{c}22 \\
236\end{array}$ & $\begin{array}{l}9 \\
8\end{array}$ & $\begin{array}{c}\text { De Boer [21] } \\
\text { Manzoni [27] } \\
\text { this paper } \\
\text { Zijderveld \& De Jong [25] } \\
\text { De Boer [21] }\end{array}$ \\
\hline 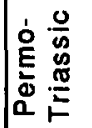 & $\begin{array}{l}15 \\
14\end{array}$ & $\begin{array}{c}\text { Bolzano area flows } \\
\text { Group I } \\
\text { W. Ljubljana }\end{array}$ & $\begin{array}{l}\text { Dolomites } \\
\text { Julian Alps }\end{array}$ & $\begin{array}{l}230-286 \\
230-263\end{array}$ & $\begin{array}{l}46 \\
43\end{array}$ & $\begin{array}{l}217 \\
235\end{array}$ & $\begin{array}{l}9 \\
9\end{array}$ & $\begin{array}{c}7 \\
19\end{array}$ & $\begin{array}{l}\text { Förster et al. [30] } \\
\text { Soffel et al. [29] }\end{array}$ \\
\hline 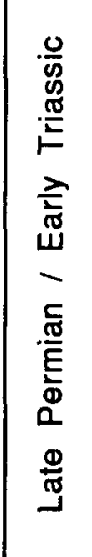 & $\begin{array}{l}13 \\
12 \\
11 \\
10 \\
9 \\
8 \\
7\end{array}$ & $\begin{array}{l}\text { Werfen Formation } \\
\text { Staro \& Camparmo } \\
\text { acid flows } \\
\text { Val Gardena } \\
\text { sandstones } \\
\text { Verrucano Lombardo } \\
\text { red beds } \\
\text { Val Gardena } \\
\text { clastics } \\
\text { Verrucano Lombardo } \\
\text { metasediments } \\
\text { Val Gardena } \\
\text { sandstones }\end{array}$ & $\begin{array}{l}\text { Dolomites } \\
\text { Lombardy } \\
\text { Vicentinian Alps } \\
\text { Lombardy } \\
\text { Dolomites }\end{array}$ & $\begin{array}{l}245-258 \\
245-258 \\
245-258\end{array}$ & 42 & 233 & 117 & 18 & $\begin{array}{c}\text { Channell \& Doglioni, } \\
\text { in press } \\
\text { De Boer [21] } \\
\text { Guicherit [28] } \\
\text { Kipfler \& Heller [6] } \\
\text { De Boer [21] } \\
\text { Kipflez \& Heller [6] } \\
\text { Manzoni [27] }\end{array}$ \\
\hline 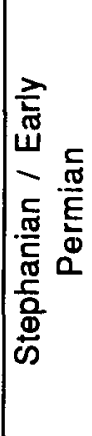 & $\begin{array}{l}4 \\
3 \\
2 \\
1\end{array}$ & $\begin{array}{c}\begin{array}{c}\text { Bolzano quartz } \\
\text { porphyries } \\
\text { combined }\end{array} \\
\text { Lugano (Ganna) } \\
\text { porphyries } \\
\text { Lower Collio \& } \\
\text { Auccia volcanics } \\
\text { Arona volcanics } \\
\text { Auccia volcanics } \\
\text { Auemig Group }\end{array}$ & $\begin{array}{l}\text { Lombardy } \\
\text { Carnic Alps }\end{array}$ & $\begin{array}{l}263-296 \\
286-296\end{array}$ & $\begin{array}{l}38 \\
36\end{array}$ & $\begin{array}{l}245 \\
243\end{array}$ & $\begin{array}{l}15 \\
47\end{array}$ & $\begin{array}{l}20 \\
14\end{array}$ & $\begin{array}{c}\text { Heiniger [24] } \\
\text { Zijderveld \& De Jong [25] } \\
\text { Heiniger [24] } \\
\text { Heiniger [24] } \\
\text { Manzoni et al. [23] }\end{array}$ \\
\hline
\end{tabular}

$n=$ number of reference for the poles plotted in Fig. $9 ; \lambda\left({ }^{\circ} \mathrm{N}\right)$ and $\phi\left({ }^{\circ} \mathrm{E}\right)=$ latitude and longitude of paleomagnetic poles; $k=$ precision parameter; $\alpha_{95}=$ half-angle of cone of $95 \%$ confidence about the pole. 
$229.3^{\circ} \mathrm{E}$ ) is in reasonable proximity to the upper Permian (Pu, 275-250 Ma), upper Middle Triassic (uTrm, 232-216 Ma), to Upper Triassic/ Lower Jurassic (Tru/Jl, 215-196 Ma) portion of the 'African' APWP. The Lower/Middle Triassic mean pole for West Gondwana $(\mathrm{Trl} / \mathrm{m})$ appears to be anomalous and may not be representative because it is based on only one observation (245230 Ma Upper Paganzo Group, Amana, Argentina [20]). In any case, the $\mathrm{PR}_{1}$ pole certainly bears no resemblance to any relevant portion of the APWP for stable Europe (Fig. 9).

The previous results from mostly Permian volcanics and sandstones from the Southern Alps generally show good agreement with the 'African' APWP (Fig. 9). Poles 1 to 13, ranging in age from Late Carboniferous to Early Triassic and with a quality index $Q$ of $\geqslant 3$ (Table 3 and [1]), are narrowly distributed along the Permian portion of the 'African' APWP, confirming the African affinity of the Southern Alps.

The available Triassic poles from the Southern Alps (poles 14 to 19) are more scattered and often have wide reported age ranges. Pole 19, from Norian (Late Triassic) dolostones from the Vicentinian Alps [21], has been plotted despite a fairly low quality index $(Q=2)$ because it is the only Triassic pole previously obtained from limestones from the Southern Alps. Its position, far removed from the 'African' APWP and close to the Late Cretaceous and Early Tertiary mean poles for stable Europe, raises the suspicion of either remagnetization or local tectonic rotation. In contrast, the $\mathrm{PR}_{1}$ pole from the Prezzo Lst. fits well with the Triassic portion of the 'African' APWP. Moreover, unlike the other Triassic poles from the Southern Alps, the $P_{1}$ pole is supported by a positive fold test and a precise age determination (latest Anisian) based on ammonoid and conodont biostratigraphy. For these reasons, the pre-folding characteristic component isolated at sites 2, 5 and 6 and which defines the $\mathrm{PR}_{1}$ pole is likely to be Middle Triassic in age and may provide a useful proxy for the African APWP. We also note that the pole (Lat. $63.8^{\circ} \mathrm{N}$, Long. $\left.230.4^{\circ} \mathrm{E}\right)$ calculated after only partial $(88 \%)$ tilt correction is virtually coincident with the $\mathrm{PR}_{1}$ pole. Nevertheless, the possibility that the $P R_{1}$ pole represents a remagnetization at an early stage of Late Cretaceous-Paleogene eo-Alpine deformation cannot be entirely discounted, given its general proximity to 'African' Late Cretaceous poles and uniform normal polarity. The eventual development of a polarity stratigraphy for Middle Triassic limestones from the Southern Alps will hopefully provide supporting evidence for original magnetizations, although reversals alone do not necessary preclude a secondary origin, as the dual polarity, Adamello-induced remagnetizations in the present study demonstrate.

Secondary magnetizations dominate at sites 1 , 3 and 4 . The directions are clearly better grouped without tilt corrections and hence were acquired after eo-Alpine to meso-Alpine deformation in the Late Cretaceous-Early Paleogene. It is most likely that these magnetizations were associated with the emplacement of the Adamello batholith and related dykes, which field observations show intruded mainly after deformation. Indeed, the fact that no improvement in the grouping of the secondary magnetizations is observed at any intermediate percentage of tilt correction suggests that no syn- or post-intrusion deformation seems to be present in the study area, at least at the outcrop scale. An Adamello-induced origin is also indicated by the relatively good agreement of the $\mathrm{PR}_{2}$ pole (Lat. $74.5^{\circ} \mathrm{N}$, Long. $172.1^{\circ} \mathrm{E}$ ) with the poles calculated from the data of Kipfler and Heller [6] from remagnetized Upper Permian metasandstones (pole $\mathrm{KH}_{1}$ : Lat. $77.2^{\circ} \mathrm{N}$, Long. $158.9^{\circ} \mathrm{E}, d_{\mathrm{p}} / d_{\mathrm{m}}=6.5^{\circ} / 9.3^{\circ}$ ) and redbeds (pole $\mathrm{KH}_{2}$ : Lat. $80.9^{\circ} \mathrm{N}$, Long. $122.0^{\circ} \mathrm{E}, d_{\mathrm{p}} / d_{\mathrm{m}}=$ $4.7^{\circ} / 6.1^{\circ}$ ) sampled in the contact aureole of the Adamello (Fig. 9). The time of remanence acquisition is therefore predicted to be around $42-40$ $\mathrm{Ma}$, which is the cooling age of the southernmost part of the Adamello batholith near the location of the sampling sites. The $\mathrm{PR}_{2}, \mathrm{KH}_{1}$ and $\mathbf{K H}_{2}$ poles are consistent with Early Tertiary mean pole positions for both stable Europe and for 'Africa', which had converged considerably by this time.

Although Adamello-induced overprinting has limited the stratigraphic coverage of characteristic magnetizations in the sections sampled, and bearing in mind that Late Cretaceous remagneti- 
zation cannot be fully discounted despite the highly positive fold test, the latest Anisian, and more precisely, the Trinodosus zone and most of the overlying Lardaroceras beds sensu Balini [9] may correspond to an interval of normal polarity with a duration of perhaps 1 m.y. Normal polarity in the late Anisian has been reported from the Muschelkalk of eastern Spain [22] and from the Han-Bulog Lst. of Hydra (Greece) [Muttoni et al., in prep.]. The present results from the Prezzo Lst. and Buchenstein Fm. suggest that the limestones of the Southern Alps are suitable material for the development of a more comprehensive magnetobiostratigraphy for the Middle Triassic. In particular, immediate further work is planned at site 6 where it should be possible to extend the stratigraphic coverage downward into the lower Anisian as well as upward into the Ladinian.

\section{Acknowledgements}

G.M. is deeply indebted to Prof. M. Gaetani for discussions and guidance throughout this research. We acknowledge $M$. Balini for useful suggestions and assistance in the field. We are also grateful to the editor and the two anonymous reviewers for their careful reviews. This is Lamont-Doherty Earth Observatory contribution 5167.

\section{References}

[1] R. Van der Voo, Paleomagnetism of the Atlantic, Tethys and lapetus Oceans, Cambridge University Press, 1993.

[2] W. Lowrie, Paleomagnetism and the Adriatic promontory: a reappraisal, Tectonics 5, 797-807, 1986.

[3] M. Gaetani, ed., Anisian/Ladinian Boundary Field Workshop, Southern Alps-Balaton Highlands, Albertiana 12, 5-9, 118 pp., 1993.

[4] P. Brack and H. Rieber, Towards a better definition of the Anisian/Ladinian boundary: New biostratigraphic data and correlations of boundary sections from the Southern Alps, Eclogae Geol. Helv. 86, 415-527, 1993.

[5] A. Del Moro, G. Pardini, C. Quercioli, I.M. Villa and E. Callegari, $\mathrm{Rb} / \mathrm{Sr}$ and $\mathrm{K} / \mathrm{Ar}$ chronology of Adamello granitoids, Southern Alps, Mem. Soc. Geol. Ital. 26, 285-299, 1983.

[6] R. Kipfler and F. Heller, Palaeomagnetism of Permian red beds at the contact aureole of the Tertiary Adamello massif (Northern Italy), Phys. Earth Planet. Inter. 52, 365-375, 1988.

[7] S. Kovàcs, A. Nicora, I. Szabo and M. Balini, Conodont biostratigraphy of Anisian/Ladinian boundary sections in the Balaton Upland (Hungary) and in the Southern Alps (Italy), Cour. Forsch. Inst. Senckenberg 118, 171195, 1990.

[8] P. Brack and H. Rieber, Stratigraphy and ammonoids of the Lower Buchenstein Beds of the Brescian Prealps and Giudicarie and their significance for the Anisian/ Ladinian boundary, Eclogae Geol. Helv. 79, 181-225, 1986.

[9] M. Balini, Lardaroeras gen. n.: a new late Anisian ammonoid genus from the Prezzo Limestone (Southern Alps), Riv. Ital. Paleontol. Stratigr. 98, 3-28, 1992.

[10] B.U. Haq, J. Hardenbol and P.R. Vail, Mesozoic and Cenozoic chronostratigraphy and cycles of sea-level change, in: Sea-Level Changes: An Integrated Approach, SEPM Spec. Publ. 42, 71-108, 1988.

[11] A. Castellarin, L. Cantelli, A.M. Fesce, J.L. Mercier, V. Picotti, G.A. Pini, G. Prosser, R. Sartori and L. Selli, Alpine compressional tectonics in the Southern Alps. Relationships with the N Apennines, Ann. Tectonicae 6, 62-94, 1992.

[12] P. Brack, Multiple intrusions-examples from the Adamello batholith (Italy) and their significance in the mechanism of intrusion, Mem. Soc. Geol. Ital. 26, 145$157,1986$.

[13] F. Forcella and F. Jadoul, Deformazioni post-Adamello nelle Alpi Orobie. Stato dell'arte ed ipotesi di lavoro, in: Studi Geologici Camerti, Volume Speciale, pp. 139-151, 1990.

[14] J.L. Kirschvink, The least squares line and plane and analysis of paleomagnetic data, Geophys. J.R. Astron. Soc. 45, 699-718, 1980.

[15] W. Lowrie, Identification of ferromagnetic minerals in a rock by coercivity and unblocking temperature properties, Geophys. Res. Lett. 17, 159-162, 1990.

[16] M.W. McElhinny, Statistical significance of the fold test in paleomagnetism, Geophys. J.R. Astron. Soc. 8, 338340, 1964.

[17] P.L. McFadden and D.L. Jones, The fold test in palaeomagnetism, Geophys. J.R. Astron. Soc. 67, 53-58, 1981.

[18] M. Gaetani and F. Jadoul, The structure of the Bergamasc Alps, Accad. Naz. Lincei, Rend. Cl. Sci. Fis. Nat. 8(66), 411-416, 1979.

[19] P. Rochette, G. Ménard and R. Dunn, Thermochronometry and cooling rates deduced from single sample records of successive magnetic polarities during uplift of metamorphic rocks in the Alps (France), Geophys. J. Int. 108, 491-501, 1991.

[20] D.A. Valencio, J.F. Vilas and J.E. Mendia, Palaeomagnetism of a sequence of red beds of the middle and upper sections of Paganzo Group (Argentina) and the correlation of upper Palaeozoic-lower Mesozoic rocks, Geophys. J.R. Astron. Soc. 51, 59-74, 1977. 
[21] J. De Boer, Geology of the Vicentinian Alps with special reference to their paleomagnetic history, Geol. Ultraiectina 11, 178 pp., 1963.

[22] P. Turner, A. Turner, A. Ramos and A. Sopena, Paleomagnetism of Permo-Triassic rocks in the Iberian Cordillera, Spain: acquisition of secondary and characteristic remanence, J. Geol. Soc. London 144, 61-76, 1989.

[23] M. Manzoni, C. Venturini and L. Vigliotti, Paleomagnetism of Upper Carboniferous limestones from the Carnic Alps, Tectonophysics 165, 73-80, 1989.

[24] C. Heiniger, Palaeomagnetic and rock magnetic properties of the Permian volcanics in the western Southern Alps, J. Geophys. 46, 397-411, 1979.

[25] J.D.A. Zijderveld and K.A. De Jong, Paleomagnetism of some Late Paleozoic and Triassic rocks from eastern Lombardic Alps, Italy, Geol. Mijnbouw 48, 559-564, 1969.

[26] J.D.A. Zijderveld, M. Hazeu and R. Van der Voo, Shear in the Tethys and the Permian paleomagnetism in the Southern Alps, including new results, Tectonophysics 10 , 639-661, 1970.

[27] M. Manzoni, Palaeomagnetic data of Middle and Upper Triassic age from the Dolomites (eastern Alps, Italy), Tectonophysics 10, 411-424, 1970.

[28] R. Guicherit, Gravity tectonics, gravity field and palaeomagnetism in northeastern Italy, Geol. Ultraiectina 14, 125 pp., 1964.

[29] H. Soffel, W. Pohl and S. Buser, Paleomagnetism of Permo-Triassic rocks from Northern Slovenia, Yugoslavia, and the eastern margin of the Adriatic plate, Tectonophysics 91, 301-320, 1983.

[30] H. Förster, H. Soffel and H. Zeinsser, Palaeomagnetism of rocks from the eastern Alps from north and south of the Insubric line, Neues Jahrb. Geol. Paläontol. Abh. 149, 112-127, 1975. 